\title{
The Struggle for Certainty: Ontological Security, the Rise of Nationalism, and Australia-China Tensions after COVID-19
}

\author{
Guangyi Pan ${ }^{1,2}$ (1) Alexander Korolev ${ }^{2,3}$ (]) \\ Accepted: 23 November 2020/ Published online: 5 January 2021 \\ (C) Journal of Chinese Political Science/Association of Chinese Political Studies 2021
}

\begin{abstract}
Australia-China relations have been relatively stable over the last decade. However, soon after the outbreak of COVID-19, Australia took an increasingly assertive stance toward China, one that is arguably even more assertive than those of its Western allies. What prompted Australia to adopt a tougher policy against China? This article argues that COVID-19 has brought significant uncertainty to the international system and, hence, to Australia's external environment, which has affected the country's decisionmaking, accelerating the formation of a hardline policy toward China. A contributing factor behind this policy is Australia's quest for ontological security, which, in the context of COVID-19, has triggered a rise in anti-China sentiment. Meanwhile, this strategy backfired when it encountered China's own nationalism, which exacerbated the widening political chasm, dragging the two countries into an unprecedented diplomatic confrontation. The core of ontological security lies in maintaining the stability of the identity needed for the formation of consistent policy. The uncertainties created by the COVID-19 pandemic have changed the familiar external environment and challenged Australia's ability to interpret this new environment and adjust to it, which has triggered ontological insecurity. By analyzing Australia's identity as a middle power in the context of changing regional security and its commitment to certain values, the article shows how COVID-19 has accelerated Australia's quest for ontological security, which has changed the country's China policy.
\end{abstract}

Keywords Australia-China relations · Ontological security $\cdot$ Nationalism

Guangyi Pan

Guangyi.pan@unsw.edu.au

Alexander Korolev

a.korolev@unsw.edu.au

Extended author information available on the last page of the article 


\section{Introduction}

Australia-China relations, which had been steadily improving since the end of the Cold War, have deteriorated drastically since 2016. COVID-19 intensified this negative trend. Australia-China relations are now deteriorating on almost every front, from political relations to social contacts. On 22 April, after a phone call with US President Donald Trump, the Australian Prime Minister Scott Morrison initiated an independent international inquiry into the origin of the pandemic, which China opposed and criticized as political maneuvering. In response, the Global Times, a Chinese state-run newspaper, condemned Australia with a nationalist tone, satirizing the country as "gum stuck to the bottom of China's shoe" and stating that "sometimes you have to find a rock and rub it down" [41]. Given both China's subsequent significant restrictions on its exchange of trade and people with Australia and Australia's new military plan outlined in the 2020 Strategic Defence Update, some argue that these reactions show that Canberra is no longer coy about publicly pointing the finger at Beijing and is now bluntly directing accusations against the latter. The bilateral relations between the two countries since these actions have plummeted at an unprecedented rate [25]. In October, Australia rejoined the Malabar exercise - a quadrilateral naval exercise held by Quadrilateral Security Dialogue (QSD) participants, such as the United States, Japan, Australia, and India.

According to Tsinghua University experts, ${ }^{1}$ the ongoing Australia-China tensions after COVID-19 demonstrate a severe deterioration of the relationship from that in previous years. As Fig. 1 shows, the recent decline (the red segment) is unprecedented, and the trend is continuing. While these data reflect assessments by China-based academics, they reveal the role of COVID-19 as an accelerator, if not a trigger, of the deterioration of China-Australia relations, which deserves special analytical attention.

Why has Australia appeared more eager than its allies, such as the UK, Canada, and New Zealand, to take a confrontational stance against China during the COVID-19 pandemic at the expense of significant economic relationships? Indeed, the roots of tension in the current Australia-China conflict can be traced back long before COVID19. Yet why did these points of tension become inflamed during the COVID-19 pandemic after years of stability in the Australia-China relationship?

Recent changes in Australia's China policy and the subsequent deterioration of Australia-China relations run counter to the predictions of conventional materialist approaches such as neorealism and neoliberalism. Material conflicts, such as trade wars, territorial frictions, and struggles for international influence, have been largely absent from, or at least have not been prominent features of, Australia-China relations. In this context, from a realist standpoint, Australia, as a key ally of the US, has made a habit of seeing the world through the latter's eyes and supporting its strategic interests [68]. However, Australia's China policy has seemed inconsistent with the US's strategic concerns and ensuing policies regarding China. Before the COVID-19

\footnotetext{
1 This chart is based on the database created by the Institute of International Relations at Tsinghua University that gauges China's relations with other powers. The database quantifies China's relations with other powers using expert-based ranking of specific diplomatic events. The values on the left axis are the bilateral relations index, where 9 is the highest level. Thus, the slope in this figure represents a significant number of negative events in the bilateral relations in a short period of time. For more details about the dataset, see http:/www. imir.tsinghua.edu.cn/publish/iis/7522/2019/20191029171434351366621/20191029171434351366621_html
} 


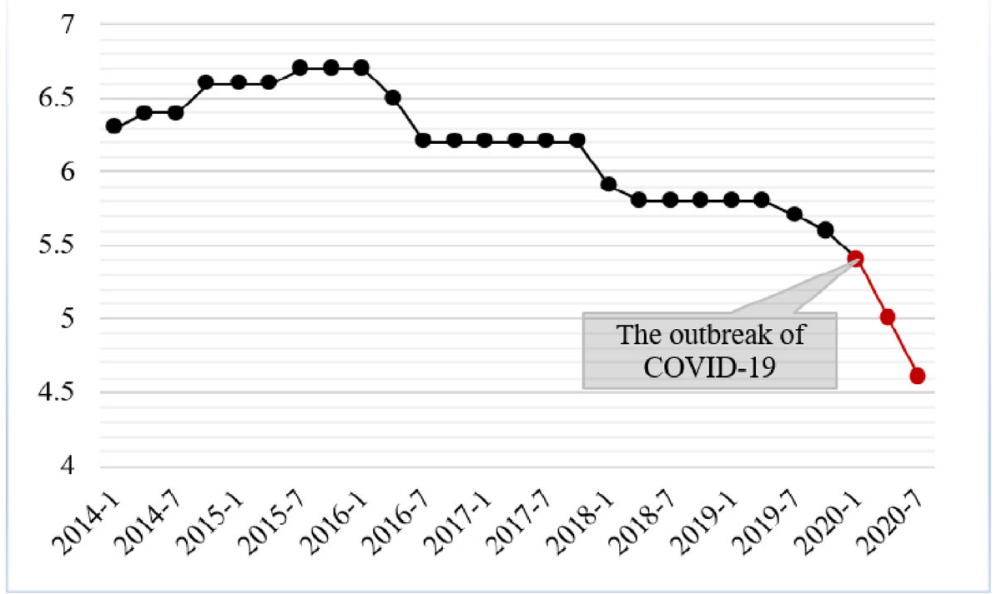

Fig. 1 Assessment of Australia-China relations (Source: Calculated by the author based on the Tsinghua University dataset 'China's Relations with Great Powers')

pandemic, as a critical partner of the US, Australia employed a hedging strategy with China in periods of heightened US-China tensions instead of simply following the stance of the US. US-China tensions predate the recent conflict between China and Australia, and security issues were not previously at the center of the Australia-China relationship, despite their prominence in US-China relations, which further challenges a realist explanation of the situation, specifically the argument about alliance behavior. Even though China's assertiveness in the South China Sea has altered Australia's stance toward China, especially since the early 2010s, security risks, if any existed, had not previously spilled over into or seriously impacted China's overall relationships until Australia's recent bout of assertiveness began. Similarly, it is difficult for neoliberalism to explain the unfolding tensions between China and Australia. China is Australia's largest trade partner, with the two-way trade being worth more than twice that between Australia and its next largest trading partner, but such significant and ongoing economic relationships and ensuing interdependence have failed to prevent bilateral relations from plummeting in a relatively short period of time.

Given the limitations of the abovementioned theoretical approaches, the theory of ontological security proposes a distinctive perspective: to cope with the shock from a critical situation, the state tends to take action to maintain the stability of self-identity and restore a favorable environment. In contrast to the materialism of neorealism and neoliberalism, the ontological security approach in IR aims to explain the motives of foreign policy from the standpoint of the interrelationship between the state's selfidentity and its external environment. This theory argues that humans need to 'make sense of their world', and when information is insufficient or previously held meanings are unreliable, anxiety prevails [51, p. 364]. The fear of chaos drives countries to be more proactive and try to restore the familiar environment and their roles in it [51, $\mathrm{p}$. 348]. In world politics, states need a continuous identity and a stable external environment that generates stable expectations. If the balance between identity and the external environment is distorted, the state may find it difficult to implement a consistent policy and will begin to modify its policies to try to restore the balance. The assumptions of 
ontological security can be used to shed light on Australia's behavioral patterns in terms of its relations with China since the outbreak of COVID-19.

Compared with other "Five Eyes" nations, Australia is more sensitive to China's threat and the uncertainty it creates, as it depends on China more than any of the other five countries in terms of both trade volume and strategic goods in critical sectors, which means that any potential change in Beijing's intentions carries a significant risk for Canberra. This vulnerability makes it all the more urgent for Australia to enhance its capability to shape the strategic environment in which Canberra can reduce the risk of uncertainty emanating from Beijing and maintain its strategic identity in relation to China.

From the perspective of ontological security, the hardening of Australia's China policy predominantly reflects the former's concerns about self-identity and its expectations regarding the future, which are rooted in a continuous concern about its role in world politics. Therefore, the sense of insecurity highlights Australia's dependence on the international system that it is familiar with. This dependence affects the country's ability to manage its insecurities [8]. In summary, this study shows how the intensifying Australia-China tensions have been exacerbated by COVID-19 and Chinese nationalism due to the considerable threat these pose to Australia's ontological security. Following changes in the recent annual reports official statements of the government, the keyword "uncertainty" now occurs more frequently than in the past, which implies that Canberra has gradually come to perceive the uncertainty of the international system due to China's rise since 2015. COVID-19 has aggravated Australia's existing worries and anxiety by disrupting routinized international behaviors, undermining UN-centered multilateralism, US-led regional security, and Australia's commitment to specific values, thus shaking Australia's familiar environment. Due to growing uncertainty about the future of the regional and global order at the systemic level, Australia tends to undertake radical policies for maintaining and securing the consistency of its identity and the relevant environment.

This article is divided into three parts. The first part reviews the theory of ontological security and operationalizes Australia's identity by assessing the roles of the biographical narrative and recognition. Analyzing these two indicators shows how Australia forms its self-identity and applies it to the external environment. After identifying Australia's identity as a middle power, the article then compares changes in Australia's China policy before and after COVID-19 with a concentration on three empirical cases - Australia's effort in the international order, the regional security in the Indo-Pacific, and Australia's commitment to specific values - followed by the explanations of ontological security. This article concludes by describing the reason for Australia's China policy, namely, the struggle for maintaining an ontologically secure external environment that preserves Australia's state identity.

\section{Certainty, Identity and Ontological Security}

Anthony Giddens contributed greatly to the concept of ontological security by explaining self-identity and the prerequisite of individual behaviors. In contrast to the more conventional concept of physical security, ontological security, as described by Giddens, is the confidence that human beings have in the continuity of their self-identity and the constancy of their surrounding social and material environments [28, p. 37]. 


\section{Ontological Security in International Relations}

The formation of ontological security is closely tied to the tacit character of practical consciousness that indicates whether a given response is either 'appropriate' or 'acceptable' [26, p. 37]. In other words, this practical consciousness determines what is normal or not in day-to-day routines and constructs the content of the logic of appropriateness. Giddens realized the negative side of the tacit knowledge within which chaos and uncertainty lurk and that ontological security stabilizes and ensures the continuity of self-identity in response to uncertainty. In sum, ontological security is the confidence in people's self-identity as a whole and the continuity of realities that emphasize the sense of faith that the known natural and social worlds are as they appear to be [42].

The core of the concept of ontological security is the confidence generated by the basic trust an individual has in other members of society, which helps reduce existential anxiety. Anxiety unconsciously forms emotive tensions that represent "internal dangers" to the awareness of self-identity [28, p. 45-46]. It is then essential to decrease anxiety related to self-identity since the stability of self-identity is a prerequisite for an individual to be able to engage in long-term planning. The quest for ontological security is thus motivated by the desire to meet the basic needs of all human beings.

How do actors with a consistent identity form a sense of ontological security? Routines characterized by repeated actions help construct a basic trust system in which individuals can obtain ontological security. A basic trust system that minimizes the uncertainty in identity building is essential for the development of ontological security. It is almost impossible for individuals to predict various external dangers that may threaten their identity. Therefore, to deal with unknown dangers and avoid being exhausted by worrying about their uncertainty, individuals depend on the basic trust system to mitigate all potential threats to a tolerable level and then minimize their anxiety about uncertainty. This trust system functions as a "protective cocoon" that filters out dangers that could threaten the ability of the self to achieve a stable continuity of identity [27]. In short, the conceptual core of ontological security is a focus on the relational constitution of the self during times of anxiety. The idea is that social actors like to feel that the environment is stable and continuous so they can achieve a sense of agency.

In IR theory, Huysmans has argued that ontological security in world politics is a strategy used to manage the limits of reflexivity that redirect a state system's aim from the elimination of enemies to alignment with norms [37]. For a state, national and international security strategies designed to identify, rank, and prioritize fears explicitly aim to minimize exposure to risk and thus keep populations safe by eradicating fear while maintaining a favorable environment and deterring the 'risk' of uncertainty [39].

Further extending ontological security to international relations, Mitzen and Steel treat state as people. States, as groups of political actors, seek ontological security just as individuals do. States can be thought of as living organisms that pursue political goals for psychological and emotional reasons since states are not physical objects but rather social constructions of the mind; they cannot be anything more than the material facts that constitute them [66]. This argument is based on two facts. First, states and individuals are emotionally connected because the state agent creates an emotional connection that promotes its authority and the "national interest," which means 
that the citizen's existential experience can only be completed through the state itself [51, p. 16]. Even though the notion of a state is abstract and constructive, it has evolved as a collective identity that embodies individuals' values, emotions, and psychological needs. Second, leaders of states who are in charge of state resources represent states, and they all share the same collective commitment to state self-identity [65, p. 19], which means that the way leaders perceive and respond to the ontological security of states matters, and this is important for the operationalization of the ontological security approach. Therefore, just as an individual would feel anxiety in discovering challenges to the basic trust system, states, personified as above, would be besieged by anxiety when their favorable strategic environment changes to the opposite conditions. States must therefore restore their favorable environment if they are aware that their self-identity cannot be maintained or they are facing potentially undesirable uncertainty.

\section{Biographical Narrative, Recognition, and the Role of Nationalism}

Identity, according to studies on international relations, is a property of international actors that generates motivational and behavioral dispositions [65]. Identity depends not only on self-understanding but also on the recognition of others and on whether such recognition is the same as self-understanding. In line with this logic, the question of whether a state's quest for ontological security will succeed is dependent on a coherent self-understanding and the recognition of others.

The process by which states stabilize their self-identity depends on two factors: internal, which concerns how the state tells others about itself, and external, which concerns how other states recognize the narrative that the state tells. Biographical narratives and the recognition of others thus matter to the operationalization of ontological security.

With regard to the internal factor, the biographical narrative is central to the stabilization of self-identity, and it also represents the approach used to construct the national identity from the perspective of self-understanding. As Ringmar claims, the question of "being" can be answered through narratives because states are constructed through the stories told about them [57]. Steel emphasizes the paramount role of internal construction that focuses on the internal factors of states in the process of identity building. A nation-state, from this perspective, is a bounded community constituted by a biographical narrative that gives meaning to its collective spatiotemporal environment [7]. It is argued that the relationship between the identity and the "biographical narrative" of the state, rather than interactions in international society, leads to the development of ontological security because the biographical narrative gives meaning and justification to states' actions [43]. Ontological insecurity and negative emotions, including anxiety and shame, arise when one's behaviors deviate from a narrative-based self-understanding. To avoid such negative emotions and feedback, states tend to use a strategy of "reflexive discourse" to rethink their behaviors and remake policy that is consistent with their identity [59].

With regard to the external factor, social interaction plays the role of harmonizing endogenous purposes and external recognition because obtaining recognition is indispensable to the self's constitutive stories [58]. Mitzen does not agree that the identity of a state is given or can be stabilized merely through biographical narratives. She stresses 
that a state's identity is dependent on social interaction with other states. The most important part of the process is stabilizing the state's identity through routinized social interaction, where social relations are formed if others respond predictably [51, pp. 347354]. During the interaction, a basic trust system is constructed for states through attachment and recognition. In this sense, a society with routinized interaction provides ontological security for its members, and international society likewise provides states with a basic and reliable mode for interactions. Nevertheless, once this practice, which is frequently taken for granted, is interrupted and the state's biographical narrative is challenged, the state must rethink its identity and the related environment.

Consequently, the state needs to continually make other states aware of the identity that the state believes it has, and others, in turn, will give feedback to the state to show whether the state's belief is reasonable. In this way, the biographical narrative about self-identity is - or is not - recognized [45]. Therefore, the state is still required to interact with others to gain recognition, and the recognition of its identity cultivates authentic self-esteem and a developed and emotional identity [44].

Nationalism and its variants are the basis of a collective identity in a time of globalization. When nationalism is embedded in a biographical narrative, the relevant policy can provide a powerful identity signifier to convey unity, security, and inclusiveness in times of crisis [38]. Hence, in the face of potential uncertainty and its resulting impact on self-identity, nationalist rhetoric becomes an effective strategy for identity maintenance because it protects the members of society from strangers, outsiders, and protects the state against ontological insecurity. In recent years, nationalism has become the primary political tool used by states to defend their identities. Nationalism hereby creates a dilemma when the state's nationalistic struggle for recognition is not recognized by others, thereby making the state more aggressive. This dilemma has appeared in the form a rise in Australia-China tensions since the beginning of the COVID-19 pandemic when Australia's goal to maintain its ontological security clashed with China's increasingly nationalistic diplomacy, which has greatly hindered bilateral relations.

Biographical narratives and recognition provide a way to operationalize the ontological security that states are seeking. A biographical narrative based on official documents and statements shows how the state views itself and the image it aims to achieve. Recognition from others demonstrates how other states perceive the state, which reflects the behaviors of the state when interacting with international society. The discourse and activities of the state during its quest for ontological security comprise the state's self-identity. This article gauges Australia's ontological security by reviewing governmental documents, statements from leaders and the international consensus of Australia's identity.

\section{Australia's Quest for Ontological Security and the Australia-China Relationship}

States tend to seek and shape a favorable environment for maintaining their self-identity so as to guarantee their ontological security. Australia is no exception to this. Its response to the changes is shaped by its self-identity and its expectations of the external environment that sustains the state's self-identity. 


\section{Anchoring Australia's Identity in World Politics}

The measurement of ontological security relies not only on a narrative but also on the actions taken to gain others' recognition. The sociality and relativity of self-identity imply that the content of ontological security may vary in different circumstances. In other words, the indicators of identity are precisely those that Australia claims regarding its identity in world politics and the actions that Australia takes to conform to these conceptions.

The middle power concept has occupied a primary position in the discourse of Australia's foreign policy for more than half a century. For many years, Australian decisionmakers have been positioning the country as an activist middle power that can maximize its influence mainly through niche diplomacy, such as diplomatic skills in specific areas, multilateral approaches and coalition building. Canberra's understanding of middle power dates back to the 1940s when Dr. H.V. Evatt became Minister for External Affairs. Evatt took great interest in securing a greater voice for Australia in world affairs by highlighting Australia's identity as an Allied country, its strategically important geopolitical position and its ability to persuade others to support a particular course of action [61]. After a series of official parliamentary speeches and debates, Australia's identity as a middle power in the postwar era gradually gained widespread attention in national politics and was accepted by both the Liberal Party and the Labor Party. In 1964, Garfield Barwick declared, "Australia is a middle power in more senses than one. It is clearly one in the general sense in which the expression is used." [16] Thus, Australia holds the identity of a middle power at various levels and is also seen by others as a middle power.

Specifically, the middle powers tend to pursue multilateral solutions to international problems, embrace positions of compromise in international disputes and use notions of "good international citizenship" to guide their diplomacy [12].

With regard to China and the Asia-Pacific region, Australia's identity as a middle power came with an increase in regionalism. Since the 1990s, Australia has sought to integrate itself into the Asia-Pacific region, aiming to construct a stable regional community, build security architecture, and intensify norms [71]. In doing so, the idea of being a middle power has been increasingly reflected in Australian diplomatic practice, with James Manicom and Jeffrey Reeves, for example, arguing that the goal of this identity is to create a stable regional order [48]. This policy objective was later defined and put into practice by Kevin Rudd as creative middle power diplomacy. Middle power diplomacy experienced great flowering from 2005 to 2010, transcending partisan disputes and determining the perspective through which Australia defines its identity and national interests. Therefore, asserting its middle power identity is also Australia's way of playing a role in world affairs. Overall, Australia's diplomacy has made being a 'middle power' part of the country's self-identity, and this not only is prominent in the country's biographical narrative but has also gained broad international recognition and support.

Although the most salient feature in Australia's diplomacy is its status as a middle power, it is not the country's only feature. A middle power always functions with other identities, such as derivative identities. For instance, a characteristic method of middle power diplomacy is coalition building with 'like-minded' countries, which notably characterizes Australia's alignment with the US and other democracies in the field of 
regional security. Australia's allyship with the US is consistent with the implication of the former's middle power identity, which also fleshes out the state's narrative: in the 2017 Foreign Policy White Paper, Australia perceived its alliance with the US as central to the former's approach to the Indo-Pacific, with such descriptors taking a central position in the country's diplomatic statement [5, p. 4], thus showing that being a firm ally of the US and other liked-mind democracies is the keystone of Australia's identity [15]. From this perspective, the identity of middle power not only encapsulates the behavior patterns of Australian diplomacy but also embodies, along with other identities, the sources and behavioral guides of ontological security.

Furthermore, the implications of being middle power, especially the pattern of building coalitions with liked-mind countries and the tendency to embrace the notion of "good international citizenship", also reveal the ideological motives and cultural aspects of Australia's foreign policy [67]. Being a good citizen in international society, as Gareth Evans has stated, requires Australia to be aware of the commitment to certain values with a concentration on "purposes beyond ourselves", such as protecting fundamental human rights and other values that the international community accepts as having a universal application [24]. Such moral pursuits behind the formation of a self-identity refer to a culturally derived set of core principles that guide Australian foreign policy, which impresses upon Australian decisionmakers the importance of the country maintaining keep close ties with other countries that share its common values in a turbulent world [22]. The quest for universal values under the umbrella of being a middle power endows Australia with both rhetoric and motives to connect its diplomacy with ideological factors.

Therefore, taking on the role of a middle power in international society and having a multidimensional interpretation of that role both constitute an Australian identity that supports its ontological security through different dimensions. Specifically, these images mirror interests in the basic trust system, where Australia can maximize them, forming the pillars of its identity and foreign policy. Different aspects of Australia's identity are often interwoven in diplomatic practice.

Overall, the implications of Australia's self-identity determine its order-building instinct in foreign policy. As specified by Carl Ungerer, the core foundation of Australia's vision of the rule-based order centers on a continuing US military primacy and leadership in Asia and the institutionalization of democratic systems of government as this is manageable and predictable [62]. In relation to China, as Hugh White argued, the rule-based order in Asia will constrain China's power by upholding the rule of international law and maintaining strong US engagement in the region [68, p. 53].

\section{Threats to Australia's Ontological Security}

The paradigm through which the Australian government views China has shifted in recent years. China's rise and its potential challenge to the world order have made Australian policymakers uncertain by creating systemic change in the distribution of power in world politics. Systemic pressure from the changing power distribution and the trend of power transition at the systemic level have affected Australia's perception of its ontological security and eventually determined foreign policy. As the interpretation of its ontological security implies, there are several empirical indicators of Canberra's quest for ontological security in the midst of changes in the international 
structure, including three interweaving aspects: the maintenance of a rules-based order, the stability of regional security, and a commitment to specific values.

Concerns about a rules-based order are often intertwined with potential threats to regional stability because the momentum of China's aggressive behaviors in the South China Sea (SCS) during the last decade has shaken the foundation of the international order, the power distribution in the region and even Australia's sovereignty. Specifically, the increasing tension between China and its neighbors shows that on the one hand, Beijing is wrestling for control of the region and for the power to enforce that rule, and on the other hand, Beijing's rapid military expansion in the SCS aims to offset or even expel the US influence on regional security. Additionally, China's institution building involving the AIIB and BRI and its rising influence on Australia itself have been treated as a revisionist plan that would threaten the international order that Australia used to rely on.

This perceived threat intensified when China refused to participate in the South China Sea arbitration in 2016. This decision brought considerable uncertainty to the region. As a middle power, Australia views its security as ultimately depending on an effective rule-based order, including in the case of the SCS dispute, the United Nations Convention on the Law of the Sea (UNCLOS) [49]. As the Department of Defence stated in its Defence White Paper 2013, "Australia has interests in the peaceful resolution of territorial and maritime disputes, including in the South China Sea, in accordance with international law, the prevention of aggression within Southeast Asia, and freedom of navigation and maritime security in the region's sea lanes." [4] In this context, China's refusal to participate in the arbitration was against Australia's expectations. The fear of uncertainty about the future escalated when the media revealed that China had been reclaiming land and building large facilities on several disputed rocks and reefs in the Spratly Islands after the arbitration took place. In this context, the dispute resolution mechanism that Australia pinned its hopes on has failed to work as expected, and China's military presence in the South China Sea has grown even further.

In addition to the uncertainty in the strategic environment, Canberra is also concerned about China's rising influence on cultural values and Australia itself. Over the last decade, Beijing has, in fact, been using the economic clout it has built up over the years to gradually expand its influence in Australia's domestic politics. In Canberra's view, its country's relationship with China is eroding its sovereignty and diplomatic autonomy, and Beijing is spreading its tentacles and dragging Australia into an uncertain future, thus threatening the democracy, national security and shared values in the region. These changes have forced Australia to review its policies and start playing a more active role in shaping the external environment in its favor rather than keeping a low profile and being diplomatically quiet.

A reconsideration of ontological security followed these structural changes and appeared in official statements. Turnbull repeatedly claimed that the stability of the current order is one of Australia's 'core strategic interests', and in Singapore in 2017, he also warned that China's ambition to become the region's leading power should be blocked by the US and its friends in Asia and that the US-led regional order should be preserved [69]. This is a clear sign that China's attempts to assert a greater influence since 2012 have been recognized as a threat to the international structure or, at least, a revisionist effort to change the structure. The 2017 Australian Foreign Policy White Paper makes it clear that the international order dominated by the US can no longer be 
taken for granted, which indicates that the Australian government is prepared for an uncertain outlook [5, p. 27].

In sum, China's expansion and dynamics in the US-China balance of power have gradually changed the international structure. Official documents from Australia show that these systemic changes have greatly affected Canberra's view of the strategic environment. The term "uncertainty" has appeared more frequently in discussions about the international system in recent years: "uncertainty", a keyword used to describe changes in the strategic environment, has been increasingly mentioned and has come to occupy an important place in official documents. Starting in 2015, in its annual reports, DFAT stated that the Indo-Pacific strategic environment is characterized by complexity and uncertainty -adjectives for the strategic environment that had never been used before but became fixed in collocation with "Indo-Pacific" and have been widely used since then. The 2017 Australian Foreign Policy White Paper states bluntly that "we are likely to face higher degrees of uncertainty and risk." These changes in discourse fully reflect Canberra's belief that an uncertain international order is emerging and that the stable and predictable strategic environment is disappearing, which has been a source of rising anxiety for Australia in maintaining its self-identity.

\section{The Ambivalence of Australia's Reactions to China's Challenge}

As Fig. 1 at the beginning of the article shows, although there has been a significant deterioration of the Australia-China relationship since 2016, the negative impact of each crisis has been effectively contained, and the two countries have quickly come to enjoy a period of stability after crises. This means that before COVID-19, neither side had the will to remove its mask and let the crisis grow uncontrollably. Therefore, although Australia perceives China as a threat, its response has been indecisive and starkly different from its reactions in the pre-COVID period.

For a long time, the hedging policy pursued by Australia was premised on structural uncertainty and viewed as an "engage and resist" strategy [40, 52]. Australia did not exactly side with the US against China until 2019 but instead worked to reduce uncertainty and rebuild the basic trust system. After 2016, Australia's China policy was caught between minimizing China's influence and mitigating China's potential reactions against the country, especially in the areas of international order, regional security, and the cultural values that Australia insists on.

In terms of international order, at the eve of the China-US trade war, Julie Bishop, a former foreign minister, implied that Australia would hold a neutral position if the US became caught in a trade war with other countries and would utilize the mechanisms of the WTO, which is a part of the "rule-based system." [29] Although the tension between China and the US has escalated since March 2018, from this perspective Australia still has common interests with China in many fields and has been deliberately distancing itself from the US. Canberra highlighted the need to resolve trade disputes through the WTO mechanisms rather than choosing a side [63], which fits with the way that middle powers tend maximize their own interests. Based on a common vision of international institutions and economic interdependence and despite being concerned about China's rise and geopolitical ambitions, Australia pursued a policy of hedging toward China, in part as a response to a perceived shift in the balance of power in the region, and preferred to remain aloof in great power competitions. 
Regarding the issue of regional security, Australia has increased its military cooperation with the US in recent years to demonstrate its identity as a US ally. According to Darwin, the US military presence has doubled since 2016, and its forces are now more diversified and more capable than before [32], which shows Australia's willingness to be part of the US's long-term "pivot" toward the Asia-Pacific region. Active efforts have also been made to align other regional powers to pay more attention to China's rise and potential challenge to the existing order. The Quadrilateral Security Dialogue, revived in 2017, has received more attention as a possible counter to actions from China. These joint actions are seen as an indicator that Australia is increasingly joining the efforts of other regional powers to respond to China's growing maritime capabilities and aggressive posture in the South China Sea [14]. However, in 2017, Australia's military cooperation was still at a low level and was deliberately designed to avoid provoking China.

Concerns about cultural values also affect Australia's attitude toward China. Australia has become increasingly aware that it must protect its democratic values from being "eroded" by China, with the result being the creation of a series of targeted bills and other actions to prevent undue interference by foreign powers. In 2018, Australia successively issued the National Security Legislation Amendment Act 2018 (Espionage and Foreign Interference) and the Foreign Influence Transparency Scheme to limit foreign influence on the Australian government's political process. Prior to that time, Australia had never acted specifically to combat foreign interference.

All of Australia's reactions to China's rising influence reflect growing external uncertainty and the perceived threat to the former's ontological security. A broad debate has arisen regarding the intensifying US-China competition. Policymakers and scholars have thus begun to review past policies toward China and to rethink both changes in the geopolitical environment and China's challenges to the international order. Since Howard emphasized the economic opportunity presented by the rise of China, Australia's China policy has fallen somewhere within the hedging zone [10]. Recently, such policies have been mired in controversy because of their assertation that Australia does not have to choose between the US and China, which has been a political mantra for bipartisan leaders whenever US-China tensions were mentioned in the past. Denial of potential great power conflicts, as Hugh White has criticized, further idealizes the wish that there would be no tension between Australia's future in Asia and its traditional links with the US, which would mean Australia could rest assured about its identity in the world [70]. Consequently, before 2020, coalition and labor policies in China and the region were broadly similar. Whether the Labor Party or the Liberal Party was in power, the aims and means of Australia's China policy, including the portions shaped by Gillard, Abbott, and Turnbull, was consistent: it involved avoiding doing anything that might be seen as violating its economic relationship with Beijing and avoiding open polemics. This logic has been consistently held by the Liberal-National Coalition since Morrison became Prime Minister. Anticipating increasing US-China competition, the government also called for a continued partnership with China and announced a \$44 million national foundation for AustraliaChina relations in an effort to build a greater understanding of the country. In other words, Australia was confident about maintaining a stable identity in a wishful "protective cocoon" in which the US could manage China's challenge, and Canberra was not prepared to risk its relations with Beijing to help Washington. 
Therefore, Australia's China policy before and in the midst of growing tensions between the US and China was subject to a range of domestic criticisms, most of which argued that Australia's hedging with China was, far from overhedging, actually underhedging due to the country's lack of political will to take more independent action. These arguments about Australia's China policy before the COVID-19 pandemic revealed that Australia was not posturing against China, but rather, it was indecisive and staying within the hedging zone, trying to find a place on the balancing-to-bandwagoning continuum.

In short, although the two parties differ in their perception of and approach toward China, there has been a form of tacit agreement between the coalition and the liberal party on how Australia should deal with China. In the abovementioned issues, Australia sees the South China Sea as a "major fault line" for regional order, and Australia holds that it is not a claimant state and does not take sides in the competing claims but rather focuses on the norms and laws of the region [5, p. 46]. Similarly, in the National Security Legislation Amendment Act 2018, the security risks from China are also neither emphatically exaggerated nor targeted. Economic engagement with China has also led the Australian government to adopt a relatively neutral and pragmatic standing on many issues. All of these components signal Australia's indecisive policy regarding China and its attempt to avoid the spotlight in great power competitions by believing and claiming that it does not have to choose sides.

Australia's hedging strategy against China is the result of a systemic stimulus transmitted by concerns about ontological security. This highlights the country's concerns about the uncertainty of the future order and possible challenges to the environment supporting Australia's identity. However, it is clear that even though the Australian government has taken precautions against China's influence, these actions were relatively small and did not directly target China. The reason for the prudency in its policy is because Australians saw the international order supporting their country's ontological security, and they were still confident that the US would finally prevail over China, meaning that US leadership and the current order would continue to form the foundation of Australia's middle power diplomacy and that potential crises could be managed [69]. However, external uncertainty has been rising since after the arrival of COVID-19, frustrating confidence in the country's previous underhedging policy and accelerating the formation of a more assertive state stance.

\section{COVID-19, the Rise of Nationalism and Australia's Ontological Insecurity}

The COVID-19 pandemic has undoubtedly created greater uncertainty in the world [47, 64], as highlighted by accelerated deglobalization and a rapid reduction in the human movement that has been a daily routine for decades. Increasing uncertainty has intensified emerging changes and had a dramatic and rapid impact on Australian economic development, thus deepening Australia's fear and sense of insecurity. Australia entered its first recession in 29 years; as Frydenberg bluntly stated, a recession is inevitable due to the close coincidence of widespread bushfires and the COVID-19 pandemic [9]. Great uncertainty has arisen that no one could have foreseen, making Australia's concerns about ontological insecurity even more urgent. 
The COVID-19 pandemic has exacerbated a wave of nationalism that has been growing in intensity over the last decade, reinforcing preexisting nationalist and protectionist waves $[1,30]$. Exclusionary nationalism during the COVID-19 pandemic has increased the decoupling of international exchanges, adversely affecting the strategic environment in which Australia acts as a middle power. The COVID-19 pandemic has had a rally-round-the-flag effect and has increased the level of nationalism among citizens [33]. With the uncertainty brought by the pandemic, predictions about the future of the world order have become more difficult, and the negative effect on multilateralism brought by nationalism has been close at hand. Therefore, for Australian decisionmakers, the upheaval caused by the COVID-19 pandemic is breeding chaos within the basic trust system, threatening the foundation of self-identity and taking Australia into unknown waters [31].

The pandemic has strengthened the state, reinforced nationalism, and created a world that is less open, less prosperous, and less free [2]. The pandemic, as an accelerator, is shaking the foundation of Australia's ontological security and its China policy in two ways: first, it has decreased globalization and multilateralism, undermining the reputation of the WHO, an organization in which Australia has been a key member and an advocator of reform; second, the political reality in the COVID19 era presents a picture that Australia fears - a world in which China's influence is more powerful and threatens both regional security and the moral values that Australia is committed to. The tension and clouded future are pushing Australia to more eagerly take action to restore the basic trust system and put biographical narratives about its self-identity as a middle power into practice.

\section{Australia's Assertiveness, Anti-China Sentiment and Increase in Uncertainty}

The first change in Australia's China policy was related to the issue of the UN-centered international order. As a middle power, Australia's attitude toward the WHO is complex: on the one hand, Canberra has criticized the WHO for its China-centric focus in an attempt to maintain its relations with the US; on the other hand, Australia's identity as a middle power means that it is unlikely to break with the WHO as completely as the US has or to overcriticize the WHO's legitimacy. Rather, the tendency toward coalition-building and multilateral approaches, both of which are implied in the identity of a middle power, are guiding Australia to cooperate with like-mind countries to reform the organization and maintain the UN-centric multilateral world order. This ambivalence became more evident after April.

The US-China tension over the WHO's policy toward COVID-19 has grown, marked by the US' scapegoating of China and hits to global economic performance [11]. For Australia, this is an opportunity to stand with Trump, reiterate its endorsement of the US-led order, and display a multilateral approach that differs from Trump's unilateralism. Beginning on 16 April, cabinet members, including Peter Dutton and Marise Payne, began criticizing the WHO for its mismanagement of the coronavirus that originated in China [72]. Australia's assertiveness reached its peak on 22 April when Morrison called for an independent inquiry into the origin of coronavirus and sought weapons-inspector-like power for the WHO [35].

Morrison's statement is more in line with what a middle power is supposed to do: Canberra limited its criticism to the WHO's relations with China while emphasizing 
Australia's long-standing engagement with and contribution to the reform of the UN agency. Only two days after Morrison's motion for the independent inquiry, he diverged from Trump's unilateral move to leave the WHO, stating, "What happens at the upper echelons of these organizations, how they operate, I think is in need of change...Australia will continue to advocate for that change with like-minded countries who share our concerns... we will certainly want to see an improved set of arrangements at the WHO, and we'll continue to push for that through the forums as a participant, as a member, as someone who understands and publicly states the value of the work that it does on the ground." [3] His office later added the following in another statement: there is a "need to work together to improve the ability of the international community - including the WHO - to respond to pandemics."

Morrison's statement shows that Australia is a middle power that realizes that the WHO's capacity is in doubt and that the uncertainty of a declining rule-based order would threaten the country's ontological security. This anxiety about the greater uncertainty has motivated Australia to seek a predictable environment in a more decisive way.

Australia's actions regarding the issue of the WHO represented two considerations of ontological security: one is that as a country that realizes that the strategic environment is changing, Australia is eager to signal a clear message to its US audience and wishes that the Trump administration would value the strategic partnership between the two countries so as to provide strategic certainty. As a founding member state of the WHO and a good international citizen, Australia must follow the logic of its identity, which requires it to actively engage in reforming international institutions for a better, more predicable rule-based order. Thus, Canberra limited its criticism of the organization, highlighted its own reputation in pursuing global health interests within the WHO framework, and sought to build an international coalition to give the WHO powers equivalent to those of a weapons inspector to avoid another possible pandemic and to restore the effectiveness of multilateralism.

Australia's anxiety about ontological security and its hardline China policy also relate to the issue of regional security. The security situation in the SCS intensified after COVID-19, showing the continuing decline of multilateralism and the rising tension of various conflicts. In April, China established an administrative district in Sansha City, which is part of the disputed area. China's routinized operations in the SCS point to its ambition to change the existing regional order. Beijing's opportunism amid COVID-19 demonstrated its ambitions to accelerate the establishment of a code of conduct in the SCS and gradually undermined US-led regional security. However, the indecisive reaction from the disunified ASEAN shows the weakness of multilateralism in this region since, on the one hand, small states are unable to play an independent role without the help of multilateral institutions. On the other hand, the US presence in the region is also facing negative impacts of the pandemic since the outbreak of COVID-19 has significantly lowered the US Navy's warship deployment capability in the Asia-Pacific region. As Defence Minister Linda Reynolds said, the uncertainty of the coronavirus pandemic means that Australia and the US need to cooperate now more than ever [23], the power transition in the SCS that has motivated Australia to shape the strategic environment in its favor is on the brink of collapse, and the country needs to realize that Beijing is ramping up its activities in this strategically important area. 
As a reaction to China's strategy and in its quest for ontological security, Australia has enacted a series of policies that align with its self-identity in order to reinforce a more favorable environment. In April, the Australian warship HMAS Parramatta conducted an exercise with three US Navy ships in the SCS that was described as a reaction against China's exploitation of the pandemic to undertake substantial expansion [56]. On 4 June, Morrison and Modi had a virtual summit in which they signed an agreement covering military deployments and reaffirmed their commitment to protecting values, such as democracy, that are related to the global good and were being challenged. In July, Australia took an important step against China's expansion by labeling China's claims to the SCS illegal. In October, Canberra rejoined the Malabar exercise, which was a complete reversal of its previous stance of avoiding the militarization of the QSD. At the strategic level, the Quad, which involves the US, Japan, India, and Australia, has also taken the opportunity to establish an 'Arc of Democracy' around China. Here, Australia's identity as a middle power wishing to stabilize the regional order anchors the presence of the US military, counters China's ideology as its response to China's radical expansion, and defends the basic trust system as the driving force of the global order.

The moral pursuit involved in the coalition-building of middle power diplomacy has become more apparent in Australia's policy since the pandemic started. The moral requirement inherent in the identity of a middle power affected not only Australia's political rhetoric of alignment with other powers but also its statement regarding Hong Kong. The turbulence in Hong Kong has been ongoing for the last year, but the coming of COVID-19 has aggravated concerns about Beijing's intervention there because the pandemic has been treated as a "golden opportunity" to crackdown on dissent and the prodemocracy movement as the rest of the world is distracted [18]. The turmoil in Hong Kong has heightened Australia's concerns about further uncertainty in its political relationship with China. As noted earlier, as a middle power, Australia has always prized its commitment to certain values and its focus on the "purposes beyond itself". This moral pursuit derived from a cultural principle provides the moral basis for the country's ontological security and guides its foreign policy. Therefore, developments in Hong Kong have undermined Australia's commitment to universal values and highlighted the urgent need for Canberra to fulfill the moral requirements of its identity. To reinforce this moral underpinning of its security, the Australian government has highlighted the values that Hong Kong protests stand for as well as the destabilizing and uncertain consequences of Beijing's actions.

On 19 April, Marise Payne stated that "the arrests of prodemocracy figures in Hong Kong that have happened in the midst of the global crisis stemming from COVID-19 is concerning. Actions that undermine stability are never acceptable, but to do so during a crisis of this magnitude erodes goodwill and trust." [54] On 1 July, only one day after the new National Security Law came into force, Marise announced that "Australia is troubled by the law's implications for Hong Kong's judicial independence, and on the rights and freedoms enjoyed by the people of Hong Kong." [55] On 10 August, Canberra issued a joint statement together with the foreign ministries of other Five Eyes nations to condemn the Hong Kong government's unjust disqualification of candidates and disproportionate postponement of Legislative Council elections [21]. These concerns about potential instability and eroding values in Hong Kong were soon translated into political discourse and included in diplomatic practice toward China.

"Democratic values" and relevant terms were mentioned 15 times in the press conference at the Australia-United States Ministerial Consultations on 29 July. The 
emphasis on the identity of democracy signaled a normative turn in which Australian leaders are moving away from their previous stance of ignoring or downplaying the ideology and shifting toward a position in which the concern for 'values' is associated with diplomatic practice. COVID-19 has also acted as an aggravator of the tension between Beijing and Hong Kong since it has given Beijing an excuse to enforce a lockdown and restrict prodemocracy demonstrations out of fear of virus transmission. As for Australia's China policy, the moral imperatives of the country's identity as a middle power have never been as highly regarded as they are now.

Unlike earlier Australia-China tensions that were quickly followed by diplomatic management, the current conflict has been exacerbated by Australia's more assertive policy. On 1 July, with the release of the Defence Strategic Update, Canberra clearly expressed that its aim is to build the Department of Defence's capacity to respond to a more uncertain external environment, especially in this era of considerable change when COVID-19 is creating even more uncertainty [19]. Compared with the 2016 Defence White Paper, the updated report emphasizes that the drivers of external stimuli have been faster than anticipated, and the purpose of shaping Australia's strategic environment is proposed as the priority in Australia's strategy [20]. In addition to setting an unprecedented goal, the new plan also shows a significant increase in the defense budget, which is expected to grow to $2 \%$ of Australia's GDP, equating to $\$ 200$ billion, in order to boost Australia's defense capability over the next 10 years. This document demonstrates that China's ambitions in the world since COVID-19 appeared have disrupted the status quo in the Asia-Pacific and pushed the Australian government to express anxiety throughout the updated report. Recently, after warning that the world has not known a time of strategic uncertainty such as this since the 1930s and 1940s, Morrison announced that the Australian government would invest $\$ 270$ billion over the next 10 years to upgrade the capability of the Australian Defence Force, including spending on cybersecurity, high-tech weapons and long-range antiship missiles [46]. All these actions illustrate that the uncertain future of the US-led regional security that has supported Australia's ontological security for decades is at the forefront of decisionmakers' concerns, and they must react effectively to maintain the strategic environment against China's revisionism in the COVID-19 era.

Overall, in the attempt to reduce uncertainty, Australia's quest for ontological security has been motivated by a desire to boost its ability to cope with the uncertainty of the pandemic. Australia's behavioral pattern adheres to the logic of being a middle power, which involves extending its influence by building multilateral coalitions. Moreover, Australia's actions, including its rejection of China's territorial claim in the SCS, its military response to China's expansion, its call for changes to the WHO, and its condemnation of Beijing's repression in Hong Kong, can be seen as more aggressive ontological security efforts - these divert from the country's previous implicit criticism and timely crisis management of bilateral tensions, adopting a more direct, more targeted and bolder approach.

\section{The Acceleration of Ontological Security-Seeking under the Wave of Chinese Nationalism}

With Australia's growing worries about the changing environment, including the rise of Chinese nationalism and Trump's aversion to multilateralism, nationalism has 
significantly exacerbated the impact of COVID-19 and its effect on Australia's pursuit of ontological security. The strong backlash from China and the chaos of the existing world order broke the "protective cocoon" in which Australia felt that it could remain out of the firing line of conflicts between great powers. Australian politicians became clearer in expressing their concerns about the uncertainty brought about by nationalism and the necessity of Australia defending its ontological security more independently. As we can see, concerns regarding nationalism are deepening the Australia-China conflict.

Following the outbreak of COVID-19, the changes in the strategic environment that could threaten Australia's ontological security have become more imminent than those that Canberra has previously had to face. Anti-Chinese sentiment is becoming a pillar of Australia's self-identity in this period. Two concerns are deepening Australia's vigilance against China in the COVID-19 era.

First, during the pandemic, both the decline in the US' prestige and China's actions in the SCS have made Australia realize that it should make more effort to maintain the "traditional" regional security system. The decline in the US' role has motivated Australia to take a more active position in defending regional security against challenges from China. Australia's attitude on the US-led order has changed, as some have argued that the incompetence of the Trump administration is the culprit in this global epidemic that is difficult to control, and the US has offered a counterexample of systems failure, and the values in this counterargument do not align with Australia's [50]. Moreover, Trump's decision to halt funding for the WHO runs counter to the diplomatic tradition of Australia, which relies on international organizations to build its influence. Based on findings from the Lowy Institute, more than $80 \%$ of Australians believe the US has handled the outbreak of COVID-19 badly, more than half say that the US will be less powerful after the pandemic, and $75 \%$ agree that China will be more powerful after it [53]. This poll illustrates just one aspect of Australia's changing attitudes regarding the postcrisis period, and this implies that there is an urgent need to take independent counteractions against China due to the increasing uncertainty. Consequently, concerns about structural pressure have been translated into Australia's recent China policy, and the COVID-19 pandemic has made Australia more anxious about the basic system of trust and its own identity.

Second, the impact of the COVID-19 pandemic on the system of global governance has shaken the foundations of Australia's identity as a middle power. To restore trust in the WHO and enhance the effectiveness of multilateralism amid the COVID-19 pandemic, Australia has consciously begun to exert influence in the international realm by acting as a more active initiator, including setting agendas and trying to shape international consensus with other like-minded countries. This deliberate effort is aimed at matching Australia's image with its self-proclaimed identity, which is the foundation of its diplomacy, signaling its efforts to obtain recognition for the biographical narrative that describes Australia as a good citizen of the international community. Australia's pursuit of its identity is clearly evidenced in Australian media. An initiative to conduct an independent investigation into China was approved even though it carries considerable economic risk and may lead to a deterioration of Australia's relations with China; this is a historic moment for Australia's international status [36]. These actions indicate that Australia has 
gained extensive international recognition and can successfully offset China's influence [5, p. 27].

Therefore, the perceived danger of the consequences of China's influence has prompted Australia to rethink its hedging strategy and to take a more active and independent role in shaping the COVID-19-era world order in its favor. By reviewing Australia's identity and the external environment it faces Australia, the country seeks to stabilize that identity, maintain its biographical narrative, and pursue ontological security that accelerates its ability to adopt a strong, direct China policy.

However, Australia's bid has been countered by China's "Wolf Warrior" diplomacy, which refers to the high-profile nationalist diplomacy conducted by Chinese diplomats through mass media and driven by a more proactive narrative strategy [13]. As Australia's pursuit of ontological security has greatly damaged China's prestige in international society, this offensive initiative has caused China to quickly form a counterattack with a nationalistic tone. China's rhetoric against Australia is not a familiar diplomatic discourse but is instead highly emotional and defiant. The angry discourse aims to reinforce both the ruling party's legitimacy at home and China's reputation by denying Australia's identity-seeking behavior [73]. China's comments, including those made by the Global Times and the Chinese ambassador, have dealt a significant blow to Australia's attempts to portray itself as an active, autonomous and influential middle power. The bilateral dialogue has descended into a verbal assault of mutual recrimination unlike anything seen in the past; this exchange has included the Chinese ambassador's blunt threat about a possible boycott of Australian products by Chinese customers and Morrison's dismissal of China's warning about racism in Australia as "rubbish". This blame game foreshadows a state of chaos that the two countries have never experienced before [17], signifying the collapse of previously routinized diplomacy. Consequently, such increasing conflicts symbolize the great divergence in Australia's narrative that has made it is impossible for Australia to become assertive and gain recognition of its identity from its most important trade partner. The theory of ontological security can be used to describe the chaotic relationship between the two countries that has created a dilemma for Australia because the more the country seeks to stabilize its identity, the more nationalistic the response of China will be, and the more chaotic its basic trust system will be.

During the COVID-19 crisis, Australia's desire for ontological security has become apparent under a wave of nationalism. Anti-Chinese sentiment is reaching a cross-party consensus. The pandemic has increased suspicion of the communist regime in Australian society, which has resulted in many politicians speaking on behalf of Beijing facing more negative comments. This trend has exacerbated the epidemic of anti-Chinese nationalism. Thus, nationalism has become a driving force in catalyzing the influence of the COVID-19 pandemic on Australia's ontological security. On the one hand, Australian politicians have intentionally or unintentionally exploited anti-Chinese sentiment to implement more positive agenda-setting-related actions in international institutions. On the other hand, the rise of Chinese nationalism due to China's successful control over the domestic spread of COVID-19 has increasingly served as a populist weapon for countering Australia's criticism. 
In conclusion, it can be seen from the increasingly tense confrontation that Australia's diplomacy with China has always revolved around the preservation of its identity and its strategic environment, which means that concerns about ontological security have been a key driver of its foreign policy formulation: as seen in the above case, the desire to be a middle power that relies on a rules-based order ground the country's approach of aligning with mind-liked countries and its commitment to the specific cultural values, which has been a driver of the evolution of Australia's China policy in the COVID-19 era.

\section{Conclusion}

This article postulates that Australia's need for ontological security in the changing world indicates the parallel need for a stable environment that endows states with a continuous identity, which is a prime motive of Australia's policymakers. Examining the content of routinized identity through which Australia can achieve ontological security, the study argues that the motive behind Australia's tougher policy toward China in the post-COVID world is maintaining the pillars of its self-identity: a middle power that relies on a rules-based order, US-led regional security, and a commitment to specific values.

In summary, although most of Australia's current behaviors preceded the pandemic, the COVID-19 crisis and rising nationalism have accelerated Australia's decision to become more decisive in its China policy. Australia's self-identity is internalized and routinized in its foreign policy, which guides its diplomatic practice. Moreover, although the familiar environment has degenerated into an uncertain threat and disorder, Australia continues to hold firm to its identity based on the biographical narrative that Australians have long shared. All of this suggests that Australia's identity is mainly supported by multilateralist institutions and the US-led regional security system. The greater uncertainty brought about by the pandemic that may undermine such institutional infrastructures frustrates Australia's ontological security and provokes the country to take action to reduce any risks and uncertainties in the "new order" [34].

\section{References}

1. Albertoni, Nicolás, and Carol Wise. 2020. International trade norms in the age of Covid-19 nationalism on the rise? Fudan Journal of the Humanities and Social Sciences. https://doi.org/10.1007/s40647-02000288-1.

2. Allen, John, Nicholas Burns, Laurie Garrett, Richard N. Haass, G. John Ikenberry, Kishore Mahbubani, Shivshankar Menon, Robin Niblett, Joseph S. Nye Jr, Shannon K. O’neil, Kori Schake, Stephen M. Walt 2020. How the world will look after the coronavirus pandemic. Foreign Policy. Retrieved from https:// foreignpolicy.com/2020/03/20/world-order-after-coroanvirus-pandemic/. Accessed 16 June 2020.

3. Associated Press 2020. Australia prime minister supports changes to World Health Organization. 24 April. Retrieved from https://newsinfo.inquirer.net/1264158/australia-prime-minister-supports-changesto-world-health-organization. Accessed 10 Nov 2020.

4. Australian Department of Defence. 2013. Defence White Paper 2013: 25. Retrieved from https://www. defence.gov.au/whitepaper/2013/docs/WP_2013_web.pdf. Accessed 10 Nov 2020.

5. Australian Government. 2017. 2017 Foreign Policy White Paper. Retrieved from https://www.dfat.gov. $\mathrm{au} /$ sites/default/files/2017-foreign-policy-whitepaper.pdf. Accessed 10 Nov 2020. 
6. Bagshaw, Eryk. 2020. No longer a joke: Why Australia's COVID-19 inquiry campaign won the day. Sydney Morning Herald. 20 May. Retrieved from https://www.smh.com.au/world/asia/no-longer-a-jokehow-australia-s-covid-19-inquiry-campaign-won-the-day-20200520-p54uoa.html. Accessed 20 Oct 2020.

7. Berenskoetter, Felix. 2014. Parameters of a national biography. European journal of international relations 20 (1): 262-288.

8. Bisley, Nick. 2016. Australia's strategic culture and asia's changing regional order. NBR Special Report 60. Retrieved from https://www.nbr.org/wpcontent/uploads/pdfs/publications/special_report_60_ australias_strategic_culture_december2016.pdf. Accessed 10 Nov 2020.

9. Blakkarly, Jarni and Goncalves, Ricardo. 2020. Australia is in recession for the first time in 29 years here's what it means for you. SBS News. 3 June. Retrieved from https:/www.sbs.com.au/news/australiais-in-recession-for-the-first-time-in-29-years-here-s-what-it-means-for-you. Accessed 15 June 2020.

10. Bloomfield, Alan. 2015. To balance or to bandwagon? Adjusting to China's rise during Australia's Rudd-Gillard ear. The Pacific Review 29 (2): 259-282.

11. Boylan, Brandon M., Jerry McBeath, and Bo Wang. 2020. US-China Relations: Nationalism, the trade war, and COVID-19. Fudan Journal of the Humanities and Social Sciences. https://doi.org/10.1007/ s40647-020-00302-6.

12. Carr, Andrew. 2014. Is Australia a middle power? A systemic impact approach. Australian Journal of International Affairs 68 (1): 70-84.

13. Chang, Yung-Yung. 2020. The Post-Pandemic World: between Constitutionalized and Authoritarian Orders - China's Narrative-Power Play in the Pandemic Era. Journal of Chinese Political Science. https://doi.org/10.1007/s11366-020-09695-3.

14. Chaudhury, Dipanjan Roy. 2019. India's fine balancing act with Quad and BRICS meet in New York, Economic Times, 28 Sept. Retrieved from https://economictimes.indiatimes.com/news/defence/indiasfine-balancing-act-with-quad-and-brics-meet-in-new-york/articleshow $/ 71338616 . \mathrm{cms}$ ?from=mdr. Accessed 10 Oct 2020.

15. Chong, Alan, and Quang Minh Pham. 2019. Critical Reflections on China's Belt \& Road Initiative, 151. New York: Springer.

16. Australia, House of representatives. 1964. Commonwealth Parliamentary Debates. 11 March: 486. Retrieved from http://historichansard.net/hofreps/1964/19640311_reps_25_hor41/. Accessed 11 Nov 2020.

17. Dalzell, Stephanie. 2020. Scott Morrison says Australia won't respond to Chinese 'coercion' over warning about universities. ABC News. 12 June. Retrieved from https://www.abc.net.au/news/202006-11/australia-morrison-china-respond-coercion-on-universities/12342924. Accessed 15 Aug 2020.

18. Helen Davidson. 2020. Hong Kong using Covid-19 crisis as 'golden opportunity' for crackdown, says arrested leader. The Guardian. 20 April. Retrieved from https:/www.theguardian.com/world/2020/apr/ 20/hong-kong-using-covid-19-crisis-as-golden-opportunity-for-crackdown-says-arrested-leader. Accessed 10 Nov 2020.

19. Department of Defence, Australian Government 2020. 2020 Defence Strategic Update. July 1. Retrieved from https://www1.defence.gov.au/sites/default/files/2020-11/2020_Defence_Strategic_Update.pdf. Accessed 11 Nov 2020.

20. Department of Defence, Australian Government 2020. 2020 Defence Strategic Update and 2020 Force Structure Plan. Retrieved from https://www.defence.gov.au/StrategicUpdate-2020/. Accessed 12 June.

21. Department of Foreign Affairs and Trade. 2020. Statement on Hong Kong. 10 April. Retrieved from https://www.dfat.gov.au/news/news/statement-hong-kong. Accessed 10 Nov 2020.

22. Downer, Alexander. 2019. A strategy for Morrison to succeed in Washington. Financial Review. 14 July. Retrieved from https:/www.afr.com/politics/federal/a-strategy-for-morrison-to-succeed-in-washington20190714-p5270n. Accessed 10 Nov 2020.

23. Stephen Dziedzic. 2020. Australia reaffirms American alliance but resists push for further exercises in South China Sea. ABC News. 20 July. Retrieved from https://www.abc.net.au/news/2020-07-29/ausmintalks-defence-south-china-sea-darwin-fuel-reserve/12501548. Accessed 10 Nov 2020.

24. Evans, Gareth. 1990. Foreign Policy and Good International Citizenship. 6 March. Retrieved from http:// www.gevans.org/speeches/old/1990/060390_fm_fpandgoodinternationalcitizen.pdf. Accessed 15 October 2020.

25. Geoff, Raby. 2020. Australia resolves China contradictions at last. Financial Review. 10 July. Retrieved from https://www.afr.com/world/asia/australia-resolves-china-contradictions-at-last-20200709-p55alr.

26. Giddens, Anthony. 1991. Modernity and self-identity: Self and society in the late modern age. University Press: 37.

27. Giddens, Anthony. 1991. Modernity and self-identity: 55. 
28. Giddens, Anthony. 2013. The consequences of modernity. Hoboken. John Wiley \& Sons.

29. Gilbert, Kieran, and Bishop, Julie. 2018. Interview with Kieran Gilbert, Sky News. Retrieved from https://www.foreignminister.gov.au/minister/julie-bishop/transcript-eoe/interview-kieran-gilbert-skynews-1. Accessed 11 June 2020.

30. Givens, John Wagner, and Evan Mistur. 2020. The Sincerest Form of Flattery: Nationalist Emulation during the COVID-19 Pandemic. Journal of Chinese Political Science. https://doi.org/10.1007/s11366020-09702-7.

31. Grant, Stan. 2020. Coronavirus has sped up changes to global order and sovereignty is making a comeback. ABC News. 13 April. Retrieved from https://www.abc.net.au/news/2020-04-13/ coronavirus-changes-to-global-order-us-china/12139216. Accessed 10 Nov 2020.

32. Greene, Andrew, and La, Xavier. 2018. US military to send large aircraft contingent to Darwin as part of troop rotation. ABC News. 24 January 2017. Retrieved from https:/www.abc.net.au/news/2017-01-24/ us-military-aircraft-marines-darwin-stars-and-stripes-australia/8206768. Accessed 15 June 2020.

33. Hiko, Aly and Wang, Austin. 2020. COVID-19 Pandemic and Nationalism. Retrieved from: https://ssrn. com/abstract=3660002. Accessed 10 Nov 2020.

34. Huang, Qingming. 2020. The pandemic and the transformation of liberal international order. Journal of Chinese Political Science. https://doi.org/10.1007/s11366-020-09698-0.

35. Hurst, Daniel. 2020. Australia making its presence felt at WHO while backing calls for major reform. The Guardian. 17 May. Retrieved from https://www.theguardian.com/world/2020/may/16/australia-makingits-presence-felt-at-who-while-backing-calls-for-major-reform. Accessed 10 Nov 2020.

36. Hurst, Daniel. 2020. Australia hails global support for independent coronavirus investigation. The Guardian. 18 May. Retrieved from https://www.theguardian.com/world/2020/may/18/australia-winsinternational-support-for-independent-coronavirus-inquiry. Accessed 21 Oct 2020.

37. Huysmans, Jef. 1998. Security! What do you mean? From concept to thick signifier. European journal of international relations 4 (2): 242.

38. Kinnvall, Catarina. 2004. Globalization and religious nationalism: Self, identity, and the search for ontological security. Political Psychology 25 (5): 741-767.

39. Kinnvall, Catarina, and Jennifer Mitzen. 2020. Anxiety, fear, and ontological security in world politics: thinking with and beyond Giddens. International Theory 12 (2): 244.

40. Korolev, Alexander. 2019. Shrinking room for hedging: system-unit dynamics and behavior of smaller powers. International Relations of the Asia-Pacific 19: 419-452.

41. Kuo, Lily. 2020. Australia called 'gum stuck to China's shoe' by state media in coronavirus investigation stoush. The Guardian. 28 April, 2020. Retrieved from https://www.theguardian.com/world/2020/apr/28/ australia-called-gum-stuck-to-chinas-shoe-by-state-media-in-coronavirus-investigation-stoush. Accessed 9 July 2020.

42. Laing, Robert. 2010. The divided self: An existential study in sanity and madness. London: Penguin U.K.

43. Lang, Anthony F., Jr. 2012. Agency and ethics: the politics of military intervention, 13. Albany: SUNY Press.

44. Lindemann, Thomas. 2011. Causes of war: The struggle for recognition. Vol. 25. Colchester: ECPR Press.

45. Lindemann, Thomas, and Eric Ringmar. 2011. International politics of recognition, 6. Abingdon: Routledge.

46. Macmillan, Jade, and Greene, Andrew. 2020. Australia to spend $\$ 270 \mathrm{~b}$ building larger military to prepare for 'poorer, more dangerous' world and rise of China. ABC News, June 30. Retrieved from https://www. abc.net.au/news/2020-06-30/australia-unveils-10-year-defence-strategy/12408232. Accessed 10 Nov 2020.

47. Makarychev, Andrey, and Tatiana Romashko. 2020. Precarious sovereignty in a post-liberal Europe: The COVID-19 emergency in Estonia and Finland. Chinese Political Science Review. https://doi.org/10.1007/ s41111-020-00165-y.

48. Manicom, James, and Jeffrey Reeves. 2014. Locating middle powers in international relations theory and power transition. In Middle Power and the Rise of China, ed. Bruce Gilley and Andrew O'Neil, 23-44. Washington: Georgetown University Press.

49. Medcalf, R. 2015. The Temperature in Canberra as the South China Sea Boils. Asia maritime transparency initiative. 4 June. Retrieved from https://amti.csis.org/the-temperature-in-canberra-as-the-southchina-sea-boils/. Accessed 8 June 2020.

50. Megalogenis, George. 2020. Beware the bully who is supposed to be watching Australia's back. Sydney Morning Herald. 21 May. Retrieved from https://www.smh.com.au/national/beware-the-bully-who-issupposed-to-be-watching-australia-s-back-20200521-p54v72.html. Accessed 21 Oct 2020. 
51. Mitzen, Jennifer. 2006. Ontological security in world politics: State identity and the security dilemma. European journal of international relations 12 (3).

52. Nadkarni, Vidya. 2010. Strategic partnerships in Asia: Balancing without alliances. London: Routledge.

53. Natasha, Kassam. 2020. COVIDPOLL: lowy institute polling on Australian attitudes to the coronavirus pandemic. Retrieved from https:/www.lowyinstitute.org/publications/covidpoll-lowy-institute-pollingaustralian-attitudes-coronavirus-pandemic. Accessed 21 Oct 2020.

54. Marise Payne. 2020. "Statement on arrests of pro-democracy figures in Hong Kong". 19 April. Retrieved from https://www.foreignminister.gov.au/minister/marise-payne/media-release/statement-arrests-prodemocracy-figures-hong-kong. Accessed 10 Nov 2020.

55. Marise Payne. 2020. "Statement on Hong Kong". 1 July. Retrieved from https://www.foreignminister. gov.au/minister/marise-payne/media-release/statement-hong-kong-0. Accessed 10 Nov 2020.

56. Reuters. 2020. Vietnam protests Beijing's expansion in disputed South China Sea as world remains occupied with coronavirus. ABC News. 20 April. Retrieved from https:/www.abc.net.au/news/2020-0420/vietnam-protests-beijings-expansion-in-disputed-south-china-sea/12165646. Accessed 10 Nov 2020.

57. Ringmar, Erik. 1996. On the ontological status of the state. European Journal of International Relations 2 (4): 439-466.

58. Ringmar, Eric. 1996. Identity, interest and action a cultural explanation of Sweden's intervention in the thirty years' war. Cambridge: Cambridge University Press.

59. Steele, Brent J. 2007. Making words matter: The Asian tsunami, Darfur, and "reflexive discourse" in international politics. International Studies Quarterly 51 (4): 901-925.

60. Steele, Brent J. 2008. Ontological security in international relations: Abingdon: Routledge: 16.

61. Ungerer, Carl. 2007. The "middle power" concept in Australian foreign policy. Australian Journal of Politics \& History 53 (4): 538-551.

62. Ungerer, Carl. 2018. Whose rules? In which order? Australian Institute of international affairs. 25 May. Retrieved from http://www.internationalaffairs.org.au/australianoutlook/whose-rules-in-which-order/ Accessed 16 Oct 2020.

63. van Nieuwenhuizen, Simone. 2019. Australian and People's Republic of China government conceptions of the international order. Australian Journal of International Affairs 73 (2): 181-197.

64. Wang, Zhaohui, and Zhiqiang Sun. 2020. From Globalization to Regionalization: The United States, China, and the Post-Covid-19 World Economic Order. Journal of Chinese Political Science. https://doi. org/10.1007/s11366-020-09706-3.

65. Wendt, Alexander. 1999. Social theory of international politics. Cambridge: Cambridge University Press: 224.

66. Wendt, Alexander. 2004. The state as person in international theory. Review of international studies 30 (2): 290 .

67. Wheeler, Nicholas J., and Tim Dunne. 1998. Good international citizenship: a third way for British foreign policy. International Affairs 74 (4): 847-870.

68. White, Hugh. 2017. Without America: Australia in the New Asia. Quarterly Essay 68: 45.

69. White, Hugh. 2017. America or China? Australia is fooling itself that it doesn't have to choose. The Guardian. 27 November. Retrieved from https://www.theguardian.com/australia-news/2017/nov/27/ america-or-china-were-fooling-ourselves-that-we-dont-have-to-choose Accessed 20 Oct 2020.

70. White, Hugh. 2017. Without America: Australia in the New Asia. Quarterly Essay 68: 45.

71. Wilkins, Thomas. 2017. Australia and middle power approaches to Asia Pacific regionalism. Australian Journal of Political Science 52 (1): 110-125.

72. Worthington, Brett. 2020. Marise Payne calls for global inquiry into China's handling of the coronavirus outbreak. ABC News. 19 April. Retrieved from https:/www.abc.net.au/news/2020-04-19/payne-callsfor-inquiry-china-handling-of-coronavirus-covid-19/12162968. Accessed 10 Nov 2020.

73. Yang, Yifan, and Xuechen Chen. Globalism or nationalism? The Paradox of Chinese Official Discourse in the Context of the COVID-19 Outbreak. Journal of Chinese Political Science. https://doi.org/10.1007/ s11366-020-09697-1.

Guangyi Pan is a PhD candidate in School of Social Sciences at the University of New South Wales. His research fields include Australia-China relations, theories of IR, and the Cold War history.

Dr. Alexander Korolev is a Senior Lecturer in Politics and International Relations in the School of Social Sciences, Faculty of Arts and Social Sciences, at the University of New South Wales, Sydney. He is currently working on a research project which explores how small and middle powers can survive and secure their national interests amidst intensifying great power rivalry. 


\section{Affiliations}

\section{Guangyi Pan ${ }^{1,2} \cdot$ Alexander Korolev ${ }^{2,3}$}

1 Newcastle, Australia

2 School of Social Sciences, Faculty of Arts and Social Sciences, University of New South Wales, Sydney, Australia

3 UNSW, Morven Brown Building, Kensington, NSW 2052, Australia 